\title{
Kristina Kočan
}

University of Maribor

\section{Problems in Translating Musical Elements in African American Poetry after 1950}

Summary

In most cases, African American poetry eschews traditional literary norms. Contemporary African American poets tend to ignore grammatical rules, use unusual typography on many occasions, include much of their cultural heritage in their poetry, and interweave musical elements into literary genres. The influence of such musical genres as jazz, blues, soul, and gospel, together with the dilemmas that occur for the translator, will be shown to great extent, since music, like black speech, is a major part of African American culture and literature. The translator will have to maintain the specific African American rhythm, blues adaptations and the improvisational language under the jazz impact. The paper presents the problems in translating post-1950 African American poetry into Slovene, and asks to what extent can one successfully transfer the musical elements within this poetry for the target culture? Inevitably, it will identify a share of elements that are lost in translation.

Key words: African American poetry, jazz poetry, blues, soul, gospel, translation, source culture, target culture

\section{Problemi pri prevajanju glasbenih elementov v afriško ameriški poeziji po letu 1950}

\section{Povzetek}

Afriško ameriška poezija večinoma zavrača tradicionalne književne norme. Sodobni afriško ameriški pesniki pogosto ne upoštevajo slovničnih pravil, uporabljajo nenavadno tipografijo, vključujejo velik del njim lastne kulturne dediščine v poezijo, hkrati pa svojo poezijo prepletajo z elementi glasbenih žanrov, kot so jazz, blues, soul in gospel. Članek oriše vpliv teh glasbenih žanrov na poezijo in dileme, ki se ob prevajanju pojavijo za prevajalca. Glasba, ki je zakoreninjena v črnski tradiciji kot tudi črnski govor sta pomemben del afriško ameriške kulture in književnosti. Prevajalec se mora truditi obdržati poseben afriško ameriški ritem v poeziji, adaptacije blues glasbe ter uporabo improvizacijskega jezika pod vplivom jazz glasbe. Članek podrobneje predstavlja probleme, ki nastanejo pri prevajanju afriško ameriške poezije po letu $1950 \mathrm{v}$ slovenščino ter do kakšne mere prevajalec sploh lahko prenese originalnost glasbenih elementov znotraj te poezije za ciljno kulturo? Neizogibno pa članek prikaže tudi del elementov, ki se skozi prevod izgubijo.

Ključne besede: afriško ameriška poezija, jazz poezija, blues, soul, gospel, prevajanje, izvirna kultura, ciljna kultura 


\section{Introduction}

This paper offers a detailed insight into the musical components of African American poetry after 1950. The musical genres jazz, blues, and soul, as well as gospel song are all part of the African American culture. African American poets tend to include these in their writing, and it is difficult to transfer a source culture into a target culture without making fatal errors or at least slightly changing meanings. Some African American poets include under the influence of jazz music the use of improvisatory language, where a poem contains a specific rhythm and a nonstandard use of language. Others tend to include elements of blues so that a poem becomes a socalled blues adaptation. Still others interweave elements of gospel songs into their poetry, or they follow the revolutionary ideas of soul music. Each musical compound and related translation problem discussed here is supported by examples, analysis, and discussion.

Some translations were made by the present author, but the basis for this study was the anthology of post-1950 African American poetry, Govoreči boben 2006 (The Talking Drum), which the author translated into Slovene together with Samo Šalamon.

The paper tries to portray all these dilemmas and possible solutions for them as well as to show to what extent African American poetry and culture can be transferred into Slovene language and culture. In addition, it will show a share of elements that are unavoidably lost in translation.

\section{Jazz elements}

For many African American writers, the musical aspect within literature is almost as crucial as the word itself. Even at the time of the Harlem Renaissance, writers, especially poets, were under the influence of music in that they interwove musical elements and poetry. Langston Hughes wrote a whole oeuvre in this mode, first jazz and blues, and later bop (poems like "Jazzonia, "The Weary Blues," "Dream Boogie," and "Lenox Avenue: Midnight"). Most African American artists after 1950 refused to use traditional forms, as they refused to be a part of the American white mainstream. The use of musical elements and black vernacular within the literature became something like an alternative pose against the white mainstream. An extreme example of such a pose was the case of Amiri Baraka: "Baraka also wants to take weak western forms, rip them asunder, and create something new out of rubble. He transposes Coltrane's musical ideas to poetry, using them to turn white poetic forms backwards and upside down" (Harris 1985, 15).

In the postwar period, jazz began developing in a new direction, and some changes occurred; bebop and bop music as well as cool jazz emerged. It was a time of jam sessions and different styles of playing: Charlie Parker, Thelonius Monk, Dizzy Gillespie, Kenny Clarke, Bud Powell, Max Roach, Miles Davis and Sonny Rollins. The sixties and the seventies were the era of avant-garde jazz; Ornette Coleman presented his composition "Free Jazz" in 1960, and this was undeniably a manifestation of a new period. Next to Coleman there were John Coltrane, Charlie Mingus and Miles Davis. Avant-garde jazz or free jazz was of immense importance for some poets and writers, since they saw it, on the one hand, almost as a source of revolution or, on the other hand, as a mode of contemplation in their poetry: 
In part, the act of visualizing jazz accounts for the range of poets engaged in the music's elusive accessibility: young black writers steeped in the tradition of black music, using poetry in part to achieve a political voice; ...women lamenting over the men who have done them wrong, poets trying to break apart the language to imitate sound; friends of jazz musicians eager to keep their spirit alive on the page, ... (Feinstein \& Komunyakaa 1991, xx).

African American poets used jazz in poetry to such an extent that the term jazz poetry emerged: "A jazz poem is any poem that has been informed by jazz music. The influence can be in the subject of the poem or in the rhythms, but one should not necessarily exclude the other" (Feinstein 1997, 2).

Michael S. Harper (1938-) is an African American poet who has used the jazz tradition throughout his writing. According to Feinstein's definition, his genre is jazz poetry, and Harper seems almost a musicologist, constantly referring to jazz musicians in his poems: "Harper's use of jazz requires an intimate knowledge of the music's history, and his references to musicians or songs demand complex and well informed associative responses" (Feinstein 1997, 128). One of the most important characteristics of Harper's poetry includes allusions to various jazz musicians. The major element in jazz is improvisation, which Harper has used in his poetry. Language becomes improvisation, reflecting musical improvisation.

Harper's poem "Brother John" is a good example of his use of improvisation in language, which he achieves by placing a specific rhythm into the poem. The rhythm is achieved mainly through alliteration. For a translator, it is important not to lose this rhythm and to preserve the alliteration, which can be difficult: "It may be possible to match the sound in other languages, but not the meaning, or, alternatively, the meaning, but not the sound" (Lefevere 1992, 20). The translator is occupied with an obvious dilemma here - to preserve the meaning or the sound? The translator has managed to do both in this poem, but such occasions are rare.

Another translation problem in this poem occurs with the words "Bird" and "bird"; the former word refers to Charlie Parker. ${ }^{1}$ It is impossible to preserve the double meaning of the word "bird" in Slovene, since there is another word for "bird," and it makes no sense to translate the nickname "Bird," since it would not be helpful to a Slovene reader if the translator wrote "Ptič," with a capital letter. It would be recommended, however, that the translator add a footnote reminding the reader that "Bird" refers to Charlie Parker and what the literal meaning is. 


\section{Brother John}

Bird, buttermilk, bird -

smack, booze and bitches

I am Bird

baddest nightdreamer

on sax in the ornithology-world

I can fly - higher, high, higher -

I'm a black man;

I am, I'm a black man -

\section{Brat John}

$\cdots$

Bird, pinjenec, ptič -

tlesk, pijača in psice

jaz sem Bird

najhujši nočni sanjač

na saksu v ornitološkem svetu

lahko letim - višje, visoko, višje -

jaz sem črn moški;

jaz sem, sem črn moški -

The poem "Dear John, Dear Coltrane" is a different example of Harper's jazz poetry. The poem is obviously dedicated to and about John Coltrane. ${ }^{2}$ The poem is a meditation on Coltrane's life. The poem begins with Coltrane's childhood and ends with the period of his disease: "Indeed, the poem is structured like a love supreme - in for parts which, as a whole, strive for a supreme love: acknowledgement, resolution, pursuance, psalm" (Feinstein 1997, 131). The language here seems no longer improvised, as in the previous example, ${ }^{3}$ yet Harper achieves a particular rhythm in the poem by repeating the words "a love supreme" and by inserting the third stanza of the poem ("why you so black?/cause I am ..."). Again, the translator must be aware of this rhythm and maintain it in the translation as much as possible. The problem in the third stanza also lies with the word "funky" - whether to translate it or keep it in the original. The word has several meanings, and it is very integrated into Slovene slang. The translator decided to keep this word in the original. Along with Coltrane, Harper uses other related allusions: "Naima" and "a love supreme." The names Coltrane and Naima (Coltrane's first wife) are not problematic for a translator, since names are usually left in the original form. However, more problematic is the allusion "a love supreme". The translator has to recognize that the poet is referring to the album that Coltrane recorded in 1964; moreover, the poet refers to the chant "a love supreme" on the album. Therefore, the translator must keep the original form.

\section{Dear John, Dear Coltrane}

Why you so black?

cause I am

why you so funky?

cause I am

why you so black?

cause I am

why you so sweet?

cause I am

\section{Dragi John, dragi Cotrane $e^{4}$}

..

Zakaj ti tako črn?

zato ker sem

zakaj ti tako funky?

zato ker sem

zakaj ti tako črn?

zato ker sem

zakaj ti tako sladek?

zato ker sem

2 John Coltrane (1926-1927), also referred to as Trane, was one of the most important and influential American tenor saxophone players and composers in the 1950s and 1960s.

3 There are other such jazz dedications in poetry, one such is Al Young's "Jungle Strut," which has also been translated into Slovene: "Of all the nights, yours were greenest, Gene, / Blue-breathing sun of your boogie-bled dad / Who, like you after him, left this dry world / A treasure tray of cocktails for the ear."

4 Translated by Samo Šalamon and Kristina Kočan. 
why you so black?

cause I am

a love supreme, a love supreme:

So sick

you couldn't play Naima,

so flat we ached

for song you'd concealed

with your own blood,

your diseased liver gave

out its purity,

the inflated heart

pumps out, the tenor kiss,

tenor love:

a love supreme, a love supreme -

a love supreme, a love supreme- zakaj ti tako črn?

zato ker sem

a love supreme, a love supreme:

Tako bolan,

da nisi zmogel igrati Naime,

tako nizek, da smo hrepeneli

po pesmi, ki si jo prikril

s svojo lastno krvjo,

tvoja bolna jetra so

izjalovila svojo čistost,

napihnjeno srce

spušča, tenorski poljub,

tenorska ljubezen:

a love supreme, a love supreme-

a love supreme, a love supreme-

The following example also shows the use of improvisational language. The poem "Snake-Back Solo" by Quincy Troupe (1943-) is dedicated to four important African American artists. Quincy Troupe argued in the Dictionary of Literary Biography that, "American speech idiom - blues and jazz forms - is a viable poetic form. At the base of American creativity is language... what black people can do with the rhythms and the words and musicians with the sound coupled with the words is extraordinary" ("Dictionary"). Troupe successfully transferred his theory into his poetry, one example of which is the following poem. He uses an extremely rhythmical language, which is the most important feature to maintain in the translation. The translator therefore does not reject Troupe's dense use of prepositions ("on in spacin on in on a riff") in the translation, since they mostly contribute to the rhythm of the poem. An interesting phenomenon is his use of the word "eye" instead of "I," and this homonym is unfortunately impossible to preserve in translation. In the poem, Troupe also uses allusions to Coltrane, Louis Armstrong, and Miles Davis. The translator leaves the names as in the original. The word "boogalooin" refers to boogaloo music, which was a popular musical genre in the 1960s. It is important for the translator to leave the word in the original.

\section{Snake-Back Solo, for Louis Armstrong, Steve Cannon, Miles Davis \& Eugene Redmond}

with the music up high boogalooin bass down way way low up $\&$ under eye come slidin on in mojoin on in spacin on in on a riff full of rain riffin on in full of rain \& pain spacin on in on a sound like Coltrane
Kačji solo, za Louisa Armstronga, Steva Cannona, Milesa Davisa \& Eugena Redmonda ${ }^{5}$

z glasbo visoko zgoraj

boogaloo basom spodaj tako tako nizko zgoraj \& spodaj pridrsim s svojim čarom $\mathrm{v}$ razmiku na $\mathrm{v}$ na riffu polnem dežja rifam v polnem dežju $\&$ bolečini razmaknem na $\mathrm{v}$ na zvoku coltranea

Translated by Samo Šalamon and Kristina Kočan. 
Amiri Baraka (1934-) shows the reader, with his poem "AM/TRAK," how experimental and improvisational jazz poetry can be. The poet ignores syntactic rules and punctuation, uses a highly improvisational language by inserting screams, onomatopoeic expressions of the saxophone, trying to imitate Coltrane's playing. For the translator, this actually does not present serious difficulties, since one leaves the "screams and screeches"' as in the original form. Another feature is the rhythm, which the poet achieves by repetition and isolated words that seem to be ripped out of context. If the translator in such cases follows the poet's rules, s/he will not encounter serious dilemmas.

\begin{tabular}{l|l} 
AM/TRAK & AM/TRAK \\
Trane, & Trane, \\
Trane, & Trane, \\
History Love Scream Oh & Zgodovina Ljubezen Krik Oh \\
Trane, Oh & Trane, Oh \\
Trane, Oh & Trane, Oh \\
Scream History Love & Krik Zgodovina Ljubezen \\
Trane & Trane \\
$\ldots$ & $\ldots$ \\
Trane was the spirit of the 60's & Trane je bil duša 60-ih \\
He was the Malcolm X in New Super Bop Fire & Bil je Malcolm X Novega Super Bop Ognja \\
Baaahhhhh & Baaahhhhh \\
Wheeeeee.....Black Art!!! & Wheeeeeee....Črna Umetnost!!! \\
$\ldots$ & $\ldots$
\end{tabular}

Another poet who was highly influenced by jazz is Carolyn Rodgers (1943-). Her poem "Me, In Kulu Se \& Karma" is actually a linguistic improvisation on two jazz albums, John Coltrane's Kulu Se Mama and Pharoah Sanders's Karma. ${ }^{7}$ The translator has to be careful about the similar features as in the case of Amiri Baraka. The translator has to achieve the same effect as the poet by extending the word by adding more vowels ("sweeeeet") or consonants ("screammmmmmmmming"). For the translator, it is not problematic when he faces vowels, because it is possible to prolong a vowel in Slovene but impossible to prolong a consonant like "c". Therefore the translator here chose to replace the prolonged $m$-form with the vowel " $i$ " (screammmmmmmming $\rightarrow$ kričiiiiiiiiiiiii) .

\footnotetext{
6 Sonia Sanchez also frequently used the feature of the scream and the screech in her poems, which shows to what extent directly influenced poetry: "yrs befo u blew away our passsst / and showed us our futureeeeee / schreech screeech screeeeech screeech / a/love/supreme, alovesupreme a lovesupreme. / A LOVE SUPREME / ScrEEEcCCHHHHHH screeeeEEECHHHHHHH / SCReeeEEECHHHHHHH SCREEEECCCCHHHH / SCREEEEEEEECCCHHHHHHHHHHHH / a lovesupremealovesupremealovesupreme for our blk / people" (a/coltrane/poem) John Coltrane recorded the album "Kulu Se Mama" in October 1965, featuring his classic quartet.

Pharoah Sanders, a tenor saxophone player, recorded the album "Karma" in 1969 as a response to Coltrane's "A Love Supreme".
} 


\section{Me, in Kulu Se \& Karma}

... sweet sweeet sweeeeet and its

me in the sky moving that way going freee where pha raoh and trane playing in my guts and its me and my ears forgetting how to listen and just feeling oh yeam me I am screammmmmmmming into the box and the box is screammmmmmmming back, is slow motion moving sound

...

\section{Blues elements}

Blues developed among African slave workers in America and was at first sung during work in the fields. Blues as a musical genre emerged around 1900 . The form of blues is very simple: usually it is $\mathrm{AAB}$ structure, when "each line or thought is stated, repeated, and then answered..." (Palmer 1981, 42). Another crucial aspect for blues is the African American oral tradition, which is apparent in all blues lyrics. One example of this is the classic tune by Robert Johnson, "Ramblin' on my Mind":

I got ramblin', I got ramblin on my mind

I got ramblin', I got ramblin on my mind

Hate to leave you my baby, but you treats me so unkind...

The theme in blues is always about painful experience and feelings of sadness, sometimes mixed with religious or subtle sexual elements. Blues is a strongly emotional genre. It became very popular among African American people, as they could well relate with the themes of the blues. Many poets adapted blues and used it in their poems, using its theme, form/structure and the black vernacular.

For Slovene readers, blues adaptations in poetry are completely new as blues does not exist in any relation to Europe. Moreover, Slovene poets never interwove musical elements and poetry. Translated blues adaptations may sound quite awkward to a Slovene reader. The translator must maintain the form with a rhyme structure, if the poet uses one. The theme has to stay as in the original. The most difficult thing for a translator is definitely the linguistic aspect of blues. African American poets use black vernacular in blues adaptations in a lexical and grammatical, even syntactical sense.

The poet Sherley Anne Williams (1944-1999) used blues almost as a poetic genre. All her poetry is infused with a blues motif: "Sometimes the blues mood is ritualistic and intrinsic, as in ... Williams's 'Any Woman's Blues'” (Liggins Hill 1998, 1358). This poem uses the AAB form, which the translator must maintain since this is, next to the blues theme, the most important feature of blues. ${ }^{9}$ There is a rhyme structure (aaa, bbb, ccc, ddd) in the poem, but in the second and third stanza there is only an approximate rhyme, where words are almost

Several other poets used the AAB blues structure and theme, like in the example of Nikki Giovanni's Master Charge Blues: "its Wednesday night baby / and i'm all alone / Wednesday night baby / and i'm all alone / sitting with myself / waiting for the telephone" 
but not exactly alike. In this poem this phonetic similarity is based on spoken language (alone, alone, home; sun, sun, gone). That is why the translator decided not to use the rhyme structure in the translation. According to Lefevere, it is better to omit the rhyme structure in the poem than to produce a translation that does not read well: "Translators who translate with rhyme and meter as their first priority often find themselves neglecting other features of the original ...” (Lefevere 1992, 71).

It is also difficult for a Slovene translator to find equivalents for the vernacular. The translator would have to find a matching dialect, but this would sound unnatural, since there is no substitution for black vernacular in Slovene language, or any language. As Landers claims: "No dialect travels well in translation. However reluctantly, the translator must recognize that dialect, at least at the level of one-to-one transference, is untranslatable" (Landers 2001, 117). The translator therefore chose to use formal Slovene language, except for the punctuation. Punctuation remained as in the original.

As is made apparent by the comparison of the original text and the translation, some features were lost along with part of the originality during the translation process. We cannot substitute black vernacular; the word "naw" has to be translated into the correct Slovene word "ne" because Slovene does not contain any other words for "no", neither in formal language, nor in dialect or slang. Similar examples occur in the last stanza ("My life ain't done yet...My song ain't through."), where there is again no equivalent in the target language for the vernacular structures in the source language. Some of the flavour of originality is unavoidably lost. However, as Lefevere emphasizes, it is better to know foreign authors and texts in translation than not to know them at all.

\section{Any Woman's Blues}

every woman is a victim of the feel blues, too.

Soft lamp shinin

and me alone in the night.

Soft lamp is shinin and me alone in the night.

Can't take no one beside me need mo'n jest some man to set me right.

I left peoples and places

tryin not to be alone.

Left many a person and places

I lived my life alone.

I need to get myself together.

Yes, I need to make myself to home.

\section{Blues vsake ženske ${ }^{10}$}

vsaka ženska je tudi žrtev občutja bluesa.

Blaga luč sveti in jaz sama $v$ noči.

Blaga luč se sveti in jaz sama v noči.

Ne morem vzeti nikogar na svojo stran rabim za šalo moškega da me spravi v red.

Zapustila sem mnogo ljudi in krajev poskušala da ne bi bila sama.

Zapustila mnogo oseb in krajev živela svoje življenje sama.

Moram se spraviti k sebi. Ja, moram se spraviti domov.

10 Translated by Samo Šalamon and Kristina Kočan. 
What's gone can be a window

a circle in the eye of the sun.

What's gone can be a window a circle, well, in the eye of the sun.

Take the circle from the world, girl you find the light have gone.

These is old blues and I sing 'em like any woman do.

These the old blues and I sing 'em, sing 'em, sing 'em. Just like any woman do.

My life ain't done yet.

Naw. My song ain't through.
Kar je bilo je lahko okno krog v očesu sonca.

Kar je bilo je lahko okno krog, no, v očesu sonca.

Vzemi krog svetu, punca, videla boš da ni več svetlobe.

To je stari blues in pojem ga kot vsaka ženska.

Ta stari blues in pojem ga, pojem ga, pojem ga. Kot vsaka ženska.

Moje življenje še ni končano.

Ne. Moje pesmi še ni konec.

The following poem, "Monday Morning Blues," by Naomi Long Madgett (1923-), is another example of blues in poetry. The structure in this poem is also AAB with a rhyme structure (aaa bbb ccc ddd) that the translator has completely preserved. However, for the sake of preserving the rhyme, some syntactic structures (word order or some additions to sentences) of the target language may sound archaic and awkward ("Kost črne mačke želim si, da bi našla, da vsaj nekaj sreče prikliče." or "Čakala sem plačilo, pa poštar prinesel je le račune, nič manj.”). Again Lefevere says:

...syntax tends to suffer most as it is stretched on the procrustean bed of sound similarity and metrical beat, and the information content is almost inevitably supplemented or altered in none too subtle ways by "padding": words not in the original added to balance a line on the metrical level or to supply the all-important rhyme word. (Lefevere 1992, 71)

And this is partly the case with this poem, when the translator added "nic manj" for the sake of the rhyme. One would have had to find a word for "instead", which would be "namesto," "namesto tega" or similar. The translator did not alter the information (or the theme) though.

Another interesting phenomenon of the blues aesthetic, which Madgett also uses in this poem, is in connection with African culture/heritage. Many blues lyrics refer to voodoo, superstition and even the devil. Madgett refers in this poem to "black cat's bones," which in African tradition are supposed to bring luck to people. This is to some extent culturally foreign to Slovene readers, as Slovene superstitious tradition also uses black cats but only in order to bring bad luck if it crosses one's path. Older Slovene people would even spit if a black cat crosses their path. 


\section{Monday Morning Blues}

All night my bed was rocky, all night nobody by my side;

My bed was cold and rocky, all night no good man by my side.

The radiator sputtered, the furnace gave a groan and died.

I woke up dreaming Friday, but Monday dragged me out of bed;

Yes, woke up dreaming Friday, Monday dragged me out of bed.

Was looking for a paycheck, mailman brought me bills instead.

Well, no one comes to see me, no one ever telephones;

Nobody but Misfortune visits me or telephones.

Wish I could find me something as lucky as a black cat's bones.

You may not see me smiling, still you'll never hear me cry;

Seldom see me smiling, never gonna hear me cry;

But I do a lot of laughing 'cause I'm too damn proud to die.

\section{Blues ponedeljkovega jutra ${ }^{11}$}

Moja postelja vso noč bila je majava, vso noč sama sem ležala;

Moja postelja bila je mrzla in majava, vso noč brez dobrega moškega ležala.

$\mathrm{V}$ radiatorju je pokalo, peč je zastokala in zaspala.

Sanjajoč petek sem se prebudila, a ponedeljek me je zvlekel iz sanj;

Ja, sanjajoč petek sem se prebudila, a ponedeljek me je zvlekel iz sanj.

Čakala sem plačilo, pa poštar prinesel je le račune, nič manj.

Ne, nihče me ne pride obiskat, nihče nikoli ne pokliče;

Nihče razen Nesreče me ne pride obiskat ali pa pokliče.

Kost črne mačke želim si, da bi našla, da vsaj nekaj sreče prikliče.

Nikoli me ne vidiš, da bi se smejala, a tudi ne, da bi jokala;

Redko vidiš, da bi se smejala, a nikdar, da bi jokala;

A pogosto se režim, saj sem preponosna, da bi se predala.

The poem "Blues" by Sonia Sanchez uses the blues theme differently from the previous two examples. The poet here alters the original blues form; Sanchez uses none of the typical blues structures. What matters the most in this poem is the theme: "In some instances, the influence is ornamental and thematic, as in Sanchez's 'Blues' ...” (Liggins Hill 1998, 1358). Sanchez decided to include the not-so-subtle sexual connotation ("... he put in the bacon/and it overflowed the pot.”) and an allusion to Bessie Smith ${ }^{12}$ (“...Yeah, bessie ...”). The translator should first know the background and be aware that the theme has to stay as it is in the original. The translator should not "explain" too much with the translation, yet one decided on a more free type of translation: “... translation designed to match the ideological and 'poetological' expectations shared by 'target readers' ..." (Lefevere 1992, 17). The translator chose the word "klobasica," which refers to "a small sausage". In the Slovene culture "klobasica" has a stronger sexual connotation than "bacon", and the translator wanted to be sure the Slovene reader grasps the true meaning. 


\section{Blues}

like when he took me to his

home away from home place

and i died the long sought after

death he'd planned for me.

Yeah, bessie he put in the bacon

and it overflowed the pot.

and two days later

when $\mathrm{i}$ was talking

i started to grin.

as everyone knows

$i$ am still grinning.

\section{Blues $^{13}$}

kot takrat ko me je peljal $\mathrm{k}$ sebi

domov stran od domačega kraja

in sem umrla dolgo iskano

smrt ki jo je načrtoval zame.

Ja, bessie, dal je not klobasico

in je zavrelo preko lonca.

in dva dni kasneje

ko sem govorila

sem se začela režati.

kot vsi vedo

se še vedno režim.

In the following example, the poem "A Poem For Myself (or Blues for a Mississippi Black Boy)" by Etheridge Knight (1931-1991) shows the reader how experimental a poet can become with the blues genre in poetry: "... contemporary black poets have experimented with the blues motif and form, as in Knight's A Poem For Myself...” (Liggins Hill 1998, 1359). As in the Sanchez example, there is no particular blues form, and the theme also differs from the theme of pain or sexuality, because the poet is calling for African American people to return to their southern roots.

The translator must be careful with syntactical structures, when the poet leaves out the auxiliary verb ("Born black in Mississippi", "I been to Detroit \& Chicago"). The poet also leaves out the subject at some points ("Been to New York city too"). The latter is not that problematic for the Slovene translator, since the Slovene language does not use the subject form explicitly before a verb, but expresses the subject in the verb form. The translator again chose to use formal Slovene.

\section{A Poem for Myself (or Blues for a Mississippi Black Boy)}

I was born in Mississippi;

I walked barefooted thru the mud.

Born black in Mississippi,

Walked barefooted thru the mud.

But, when I reached the age of twelve

I left that place for good.

Said my daddy chopped cotton

And he drank his liquor straight.

When I left that Sunday morning

He was leaning on the barnyard gate.

Left her standing in the yard

With the sun shining in her eyes.
Pesem zame (ali Blues za mississippijskega črnega dečka) ${ }^{14}$

Rojen sem bil v Mississippiju;

Bos sem hodil po blatu.

Rojen črn v Mississippiju,

Hodil bos po blatu.

A, ko sem jih dopolnil dvanajst

Sem zapustil tisti kraj za vedno.

Pravim očka je obiral bombaž

In ga dobro dajal na zob.

Ko sem odšel tistega nedeljskega jutra

Se je naslanjal na vrata dvorišča.

Jo pustil stati na dvorišču

Z lesketajočim soncem $v$ njenih očeh.

Translated by Samo Šalamon and Kristina Kočan.

14 Translated by Samo Šalamon and Kristina Kočan. 
And I headed North

As straight as the Wild Goose Flies,

I been to Detroit \& Chicago

Been to New York city too.

I been to Detroit \& Chicago

Been to New York city too.

Said I done strolled all those funky avenues

I'm still the same old black boy with the same old blues.

Going back to Mississippi

This time to stay for good

Going back to Mississippi

This time to stay for good-

Gonna be free in Mississippi

Or dead in the Mississippi mud.
In odšel sem na Sever

Naravnost kot letijo divje gosi,

Bil v Detroitu \& Chicagu

Bil tudi v mestu New York.

Bil v Detroitu \& Chicagu

Bil tudi v mestu New York.

Rekel dovolj mi je pohajkovanja

po vseh teh sumljivih avenijah

Še vedno sem tisti stari črni deček z

istim starim bluesom.

Grem nazaj v Mississippi

Da ostanem tam za vedno

Grem nazaj v Mississippi

Da ostanem tam za vedno -

V Mississippiju osvobojen

ali pa mrtev v mississippijskem blatu.

\section{Soul elements in poetry}

Like jazz and blues, soul music also had an impact on African American literature. Soul music derived from blues and gospel. James Brown, Aretha Franklin, Otis Redding, Stevie Wonder, Marvin Gaye and many more influenced a number of African American poets from the sixties and, later, poets like Amiri Baraka, Nikki Giovanni, Ntozake Shange, Michael S. Harper and Jayne Cortez. James Brown's "Say it Loud, I'm Black and I'm Proud" was almost the black anthem in the sixties. Soul musicians influenced the poets exactly because they expressed similar ideas in their lyrics: "The lasting legacy of pop, funk, and soul artists to the written texts of African Americans derived from their profound recognition of human alienation and the black rhythms of existence that define it" (Liggins Hill 1998, 1361). Soul music in literature was more thematically present, and not like jazz or blues where poets used improvisatory language, as in the case of jazz influence, or the blues structure/form, motif, and theme, as in the case of blues influence.

In the poem "Revolutionary Music" by Nikki Giovanni, the poet refers to soul music as revolutionary music. In a way the poet expresses the delight of soul music for black people; on the other hand the poet tells black people to reject white values; hence the title Revolutionary Music, revolution and delight.

For the translator of such poetry, it is important that he becomes familiar with the names of the artists to whom the poet alludes. The translator should also notice that the poet inserted parts of lyrics by Brown and Franklin, which are not supposed to be translated. However, it would be recommended that the translator add a footnote with a translation of the lyrics. 


\section{Revolutionary Music}

james brown can go to

viet nam

or sing about whatever he

has to

since he already told

the honkie

"although you happy you better try

to get along

money won't change you

but time is taking you on" 15

...

aretha said they better

think but she already said

"ain't no way to love you"16

(and you know she wasn't talking to us)

\section{Revolucionarna glasba}

james brown lahko odide $\mathrm{v}$

vietnam

ali poje o čemerkoli

mora

saj je že povedal

belčku

"although you happy you better try

to get along

money won't change you

but time is taking you on"

aretha je rekla naj raje

razmislijo a sama je že povedala

"ain't no way to love you"

(in veš, da ni govorila nam)

\section{Gospel}

A specific cultural expression in African American poetry is its inclusion of gospel. Gospel comes from the words "god spell." African American poets include gospel as in the sense of a sermon, typical of the black church or the Baptist church. They either add biblical allusions or write a song in the way a sermon would be written. African American poets are often influenced by gospel music in their poetry: "...black gospel music emerged in the 1920s as the urban music counterpart to the rural spirituals" (Liggins Hill 1998, 777). In gospel songs they sing about Jesus and figures from the New Testament. Hand clapping, foot tapping and other rhythmic movements, together with constant shouts of "hallelujah," are part of the gospel song. There is also the technique "call and response," whereby someone sings a phrase or a word, and the chorus echoes it, and they repeat this. Michael S. Harper interweaves this precise technique into his poem "Dear John, Dear Coltrane." The third stanza of the poem, written in italics, evokes a gospel song, a song within the poem. Feinstein expands on this:

"The antiphonal, call-response / retort stanza," Harper explains, "simulates the black church, and gives the answer to renewal to any question - 'cause I am' "... Harper refers to Coltrane's father's church, yet the phrase "cause I am" is more than a rhythmic pattern, it is an expansive answer, with the "I" encompassing "all"... (Feinstein 1997, 130)

To sing in the first person is only one feature of gospel song. For the translator, it is crucial to maintain the strong rhythm with repetition in translation and to transfer the feeling of a song so the Slovene reader can grasp the connection to gospel. 


\section{Dear John, Dear Coltrane}

Why you so black?

cause I am

why you so funky?

cause I am

why you so black?

cause I am

why you so sweet?

cause I am

why you so black?

cause I am

\section{Dragi John, dragi Coltrane ${ }^{17}$}

Zakaj ti tako črn?

zato ker sem

zakaj ti tako funky?

zato ker sem

zakaj ti tako črn?

zato ker sem

zakaj ti tako sladek?

zato ker sem

zakaj ti tako črn?

zato ker sem

Nikki Giovanni wrote the poem "The Great Pax Whitie" using a technique for writing a gospel sermon with a biblical theme - repetition ("be still") and calls to Jesus or the lord. Giovanni expresses anger, and so in places the tone is quite sarcastic: "The rage felt by so many Black Americans at America's persistent and destructive racism is registered in poems like the fine 'Great Pax Whitie'..." (Fowler 1996, 1). In the poems there are also other allusions, such as to Pax Britannica or even to the assassinations of John F. Kennedy and Malcolm X; yet all underneath the "gospel form." There are no major dilemmas for the translator; the biblical expressions are known to Slovene readers. The difference is that the Roman Catholic sermon is far more static without shouts or repetitions.

\section{The Great Pax Whitie}

In the beginning was the word

And the word was

Death

And the word was nigger

And the word was death to all niggers

And the word was death to all life

And the word was death to all peace be still

The genesis was life

The genesis was death

be still peace be still

Noah picked his wife and kiddies up for a holiday

row row row row your boat

be still be still

...

hallelujah jesus

\section{Veliki Pax belček}

Na začetku je bila beseda

In beseda je bila

Smrt

In beseda je bila črnuh

In beseda je bila smrt vsem črnuhom

In beseda je bila smrt vsemu življenju

In beseda je bila smrt vsemu

mir bodi vedno

Geneza je bila življenje

Geneza je bila smrt

…

$$
\text { bodi vedno mir bodi vedno }
$$

Noe je vzel svojo ženo in otročičke na počitnice

veslaj veslaj veslaj v svojem čolnu

...

bodi vedno bodi vedno

...

aleluja jezus

Translated by Samo Šalamon and Kristina Kočan. 


\section{Conclusion}

The main focus of my paper has been on problems in translating musical elements within this poetry into Slovene - though not only on problems in translating this poetry into Slovene, but transferring the source culture for the target culture. This part of my work, presenting the musical aspect of African American poetry, shows to what extent African American poets have been under the influence of music. Music as well as Black speech is considered to be "indigenous" to African American writers. Jazz and blues, and even soul music have influenced a number of African American poets in writing after 1950. Translators of African American poetry cannot afford to ignore this feature, since they are immediately confronted with the question of how to retain the specific African American rhythm and the improvisational language. The most difficult issue for the translator is undoubtedly the influence of the blues aesthetic on their poetry. Poets adapt the rules that apply to blues within the genre of poetry, rules on the form, theme and linguistic aspect of blues. For the translator, it is very difficult to transfer this genre into a culture that has not been specifically exposed to blues. Soul music influenced some poets because the soul musicians shared ideas in their lyrics similar to the ideas of rebellious poets of the sixties. Moreover, there is the tradition of gospel and gospel song in African American poetry which shows how valuable the cultural tradition is also to the contemporary African American poets.

This part of my work is surely incomplete; one could always find more dilemmas in the process of translation. My attempt was to present the most obvious dilemmas and problems the translator might immediately encounter when translating such poetry.

Part of the African American originality is certainly lost through the process of translation. One cannot transfer blues adaptations in poetry into Slovene without sounding awkward and unnatural; neither can one replace Black Vernacular speech with any of the Slovene dialects. However, as Lefevere says, it is better to know the foreign authors than not to know them at all, and this assurance motivates translators to bring this body of poetic work to the Slovene reading public.

\section{Bibliography}

Baraka, A. 1995. Transbluesency: The Selected Poems of Amiri Baraka. New York: Marsilio Publishers.

Dictionary of Literary Biography on Quincy Troupe. 2007. Book Rags.

http://www.bookrags.com/Quincy_Troupe (accessed August 20, 2007).

Feinstein, S. 1997. Jazz Poetry: From the 1920s to the Present. Westport: Praeger Publishers.

Feinstein, S., and Y. Komunyakaa. 1991. The Jazz Poetry Anthology. Bloomington: Indiana University Press.

Fowler, V. 1996. Foreword. The Selected Poems of Nikki Giovanni. New York: William Morrow and Company, Inc., 1-12.

Giovanni, N. 1996. The Selected Poems of Nikki Giovanni. New York: William Morrow and Company, Inc.

Harper, M.S. 2002. Songlines in Michaeltree: New and Collected Poems. Chicago: University of Illinois Press.

Harris, W.J. 1985. The Jazz Aesthetic: The Poetry and Poetics of Amiri Baraka. Columbia: University of Missouri Press. 
Hill Liggins, P., ed. 1998. Call and Response: The Riverside Anthology of the African American Literary Tradition. Boston: Houghton Mifflin Company.

Kočan, K., and S. Šalamon. 2006. Govoreči boben: Antologija afriško ameriške poezije po letu 1950. Murska Sobota: Zveza kulturnih društev, Edicije revije Separatio.

Landers, C.E. 2001. Literary Translation. Clevedon: Multilingual Matters, Ltd.

Lefevere, A. 1992. Translating Literature. Practice and Theory in a Comparative Literature Context. New York: The Modern Language Association of America.

Palmer, R. 1981. Deep Blues: A Musical and Cultural History of the Mississippi Delta. New York: Penguin Books. 